\title{
An Understanding towards Organisational Change in Swimming in the United Kingdom
}

\author{
Ian Arnott \\ Teesside Business School, University of Teesside \\ Middlesbrough, Tees Valley, TS1 3BA, UK \\ Tel: 44-1642-342809Ｅmail: i.arnott@tees.ac.uk
}

\begin{abstract}
Sports all over the world have evolved considerably over the last two decades due to their increased popularity through various marketing communication channels and the mass media coverage. Because of this they have had take on what was originally an amateur role to more a professionalised role dealing with increased governmental pressure and also in some cases quality frameworks which they once did not have. Because of this a lot of National Governing bodies who came from predominantly voluntary roles are now paid and also working with highly trained staff.

Because of this change it could be argued there has been a great deal of resistance to this which inherently has impacted the growth and development of the grass roots stages that feed into sport (Not-for -profit sports clubs). Some key researchers such as Hoye (2004, 2002), Kikulis, (2000), Kikulis., Slack,, \& Hinings . (1995) have been the lead people with in this field to look at models like Laughlins (1991), Dawsons (1996) and many other theorists' models that have been adopted when they have been going through the change process. Some of the sports that have been looked at when they have been going through this change process are NSO's in Canada and also Rugby in Australia. However there has been very little work done on sport with in the United Kingdom.
\end{abstract}

This paper looks at the Formerly Amateur swimming Association now British Swimming on how they have gone through change and in what this has impacted there grass roots development. It also looks at 30 clubs in particular on how they have embraced this change.

Key words: Organisational design, Environmental disturbances, Professinalised, Development

\section{Introduction}

Organisations are in a constant state of change; new people enter the organisations, some leave, parts of the organisation, and new programs or product lines are developed (Slack, 1997). The paradoxical nature of change stems from the fact for any organisation to remain competitive they must make change (Peters, 1990). At the same time managers need to look for new markets, new technology, and innovative means for service delivery, therefore in the service industry they must find that stability (Miller, 1990).

Achieving a balance between stability and change is not an easy task (Slack, 1997). The organisation must recognise the need for change and understand how it can be successfully implemented and managed. Changes in the environment and technology will impact the amount of change a service industry sector organisation will require. Those organisations that operate in stable environments with routine technologies will require less change than those facing dynamic environments with non routine technology (Zucker, 1989). It could be argued due to the development of technologies and the changes in the organisations environments, change could be forced upon them and subsequently there me be some resistance to this. Some examples of this are sports organisations (Miller, 1990). Due to the development and advancement of some of the organisations with in this particular area they go through what Kimberley (1980) highlights is the life cycle approach. Kimberley (1980) goes onto describe these as the creation, transformation and decline (pg 217); birth, growth, maturity, old age and death (Adizes, 1979); the entrepreneurial stage, the collectively stage, the formalisation and control stage; the elaboration of structure stage, (Cameron \& Whetton, 1983a). Where as Institutional theorists (Oliver, 1991, Zucker, 1983 \&1987); suggest that organisations change their formal structure to conform to expectations within their institutional environment about appropriate organisational design. Many countries such as England in athletic games pay high attention to organisational design in the way sport is managed (Laois, 1995). However, this maybe so, it does inhibit the development of an area that services people and other organisations with in it. Therefore for an organisation to change and conform to the expectations of their institutional environment especially such areas as a service it must do so in a legitimate way, and thus to ensure a continued flow of management and resources necessary for their operations (Hinings and Greenwood, 1988). Another example of this is the Canadian national sports organisations in the period 1984-1988 when the Canadian government 
agency Sport Canada created institutional pressures for these organisations to adopt a more professional and bureaucratic structure (Slack \& Hinnings, 1992, Macintosh \& Whitson, 1990). Also it has been identified in recent studies is that these static models on organisational design and structure are being displaced by dynamic models, reflecting a discontinuous nature of organisational change (Nelson, 2003, Fomburn, 1992, Greenwood and Hinnings, 1988 \& Pettigrew, 1985). In the service industry such as sport, change cannot be relied upon to occur at a steady state, rather than that there are periods of incremental change sandwiched between more violent periods of change which have contributed to the illusion of stability once assumed to be the case (Nelson, 2003). It must be then thought of because of the changing dynamics and environment of the service industry, organisations must adopt change.

\subsection{Organisational Change, its development with in the field of the service industry}

Organisational change has received a great deal of attention in the field of organisational design and management and structure (Kikiluis, Slack \& Hinings 1995, Skinner, Stewart \& Edwards, 1999 and Rowley, 2004). It is essential to understand why organisations might change with in this sector of the industry, and possibly what specific areas they might need to change?

The service industry is very diverse in nature and crosses a multitude of providers from private, for profit settings and public and non-profit settings (Ferkins, Shilbury \& Mcdonald, 2005). There is a well established body of literature on the differences between public sector companies as it pertains governance, delivery, service and reputation explains these distinctions (Miller-Milliesen, 2003, Miller, 2002, Olsen 2000, Forbes \& Milliken, 1999, Gopinath, Siciliano, \& Murray 1994). According to Shilbury (2001), the key distinction can be found in the purpose for existence. Financial motives and the responsibility to create shareholder wealth dominate the mission of for profit organisations. Non-profit organisations, in contrast, are motivated by preponderance of goals and outcomes (Perkins, Shilbury \& Mcdonald, (2005) such as increased members to the organisation or fundraising similar to an organisational model presented by Pettigrew (1985) (Figure 1).

Unfortunately Pettigrews (1985) model does not allow for the comprehensive environment externally and has a stronger bearing on the internal mechanisms that drive the organisation at that given time. It could be argued that the whole process is still dynamic and therefore it could be applicable to providers in the voluntary capacity of the service industry such as sport (Nelson, 2003).

A number of studies have focused on the mechanics of change in the professionalisation and the bureaucratization that has occurred within voluntary (not for profit) sport organisations that has taken place over the last two decades (Hoye, 2004, Kikulis, Slack and Hinings, 1995a, 1995b, 1995c; Slack and Hinnings 1994, 1992, Thibault, Slack and Hinnings, 1991, Slack, 1985). In addition to a concern with the patterns of change, there has also been some theorising about, and investigation of, the extent to which organisational change is likely to take place in some elements of structure and systems rather than others (Hinnings and Greenwood, 1988; Kanter, 1983). Some organisational elements may be particularly difficult to change because of the embodiment of deeply held values, yet may need specifically changing in order to signal the purpose and seriousness of change (Schein, 1985; Kanter 1984) within their environment. Dawson (1996) provides a framework in some way to attempt to discuss this (figure 2). His approach, displays a number of bundles offering components of change, which he refers to as determinants.

However, a weakness of the model of change is that it does not take into account the dynamic quality of change that Pettigrews (1985) model does. It has a static approach and does not support any type of dynamic movement forward.

So far the argument has been in general terms with regards to change (Kikulis, Slack \& Hinnings, 1995). It is important, however to recognise that different sectors are seen to carry different organisational design and functional requirements (Child and Smith, 1987). One constantly evolving sector is the provision of sport in the changing dimensions of how it is managed and developed. Sport because of its unique environment has encountered a number of disturbances because of this process (Skinner, Stewart \& Edwards, 1999), especially in the United Kingdom. Sport and there National Governing Bodies (NSO's) have and are still going through systematic and environmental change because of having to take a more business type approach and generate their own funding. Therefore they having to work in an environment with more professionalised staff and develop newer departments such as Public Relations and more.

\subsection{Environmental Disturbances in Sport}

One of the studies that was undertaken by Kikluis, Slack and Hinnings (1992) was when they identified specific environmental disturbances in their analysis of institutionally specific organisations (Skinner, Stewart and Edwards, 1999). It was discovered institutionally specific sports organisations (NSO's) create their own values, rules, myths and symbols, which strongly influence the way they respond to the demands of new environmental conditions. Also Hoye and Stewart (2002) highlighted that a large proportion of these sports organisations draw upon forms of power from volunteers, especially during periods of organisational change. Therefore it could be argued that if organisations are a not for profit, traditionally like NSO's in the UK, how would they be able to adapt to a more competitive and dynamic environment which then becomes more complex in nature similar to the design presented by Dawson (1996)? Also 
because of this complexity there is more beaucracy to deal with. Furthermore if there is a degree of professionalisation how will this affect the effectiveness and efficiency on what has been seen predominantly voluntary in nature where there is no payment to the employee's? Studies have explored the nature of this change (Hoye, 2004, Skinner, Stewart and Edwards, 1999, Kikulis, Slack and Hinnings, 1995), the sources of commitment and also the resistance to change subsequently developing bureaucracy with in the sports organisation, therefore slowing down the decision making and evolution of the NSO's.

\subsection{Evolving National Sports Organisations}

During the 1980's and the early 1990's National Sports Organisations (NSOs) have had to make adaptations in their programmes in an effort to enhance the effectiveness of the delivery of amateur sports services (Kikulis et al, 1995). This marked the beginning of a movement from simply structured and volunteered -governed organisations towards a more professional and beaurcratic form. Furthermore other studies have focused exclusively on decision making and particularly on the distributions of influence among board members and executives within the formal structure of voluntary sports organisations (Auld and Godbey, 1998, Auld, 1997; Inglis, 1997; Macintosh and Whitson, 1990). These studies however illustrated the complex nature of decision making with in the voluntary sports organisations and furthermore suggested that perceived control over decision making has the potential to be a major source of conflict between voluntary board members and executives (Hoye, 2004). However the traditional values of voluntary governance that underpinned the structures and systems of these organisations were subject to change (Kikulis et al, 1995). In a fast moving environment, governance remains central to the effective and efficient management of sport organisations (Hoye \& Auld, 2001).

Changes in sport management (e.g., the shift from a committee or council of representatives to a modern board of directors, the introduction of paid executives, player payments, increases in income and expenditure, media scrutiny and a wider range of stakeholder interests) have presented major strategic issues to those responsible for governing sport organisations (Ferkins, Shilbury \& Mcdonald, 2005, ii). So as well the dynamics of the organisation changing to a new environment and adopting a more professionalised approach bringing in paid staff, so have board members. Traditionally being of a voluntary nature and the devolution of power being held by the volunteers, the paid professional now takes on that power and facing resistance. Thibault, Slack \& Hinnings (1991) investigated structural changes in Canadian National Sport Organisations (NSOs) that occurred as a result of the introduction of paid professional staff. There research found that following the hiring of professional staff, the pattern of centralisation initially increased and decreased (Hoye \& Cuskelly, 2003). This pattern can be attributed to volunteers initially fearing the challenge that the professional poses to the culture of voluntary sports organisations (Thibault et al., 1991, p 93). However Inglis (1997) found that volunteers and paid staff still preferred to be involved in the decision making within a board setting, and also on the nature of decisions being made. This was imperative to the nature of decision making and supports theory suggested by Taylor and Ho (2005) who indicate that change is imperative for sport and is unique to all the sports organisations especially with in the environment it operates.

Other sport literature suggests that while sport organisations have traditionally had relatively unsophisticated management systems, change is becoming common practise. Therefore organisations are having to become more 'professional' in the way they approach people management issues (Chelladurai, 1999). Because of this change studies such as Kikulis et al (1995), Slack and Hinnings (1992 \& 1994)) Thibault et al (1991) and Slack (1985) have explored the nature of professionalisation, the sources of commitment and resistance to change, and the impact professionalisation has had upon decision-making structures with the organisation. One example of this was research carried out by Hoye and Cuskelly (2003) who commented on the pressure faced by voluntary sport organisations to adopt a centrally derived model and how this related to the performance of a board in their decision making process.

\subsection{Sports Organisational Structural change; rhetoric or the future on decision making}

Kilkulis et al (1995) categorised sport organisations into three different organisational archetypes; the traditional kitchen-table style, the transitional boardroom, and the business like executive office. Taylor and Ho (2005) go onto describe in the kitchen-table archetype volunteer management is paramount and the selection is based on organisational loyalty and there is little formal planning or policies. The boardroom archetype is dominated by a volunteer controlled hierarchy, but is supported by professional staff. Development of technical expertise among professional staff and increasing administrative efficiency is practised in this type. In the executive -office archetype, technical expertise is required in both professionals and volunteers (Taylor and Ho, 2005; 113). What is clearly evident is that historically National Sports Organisations (NSO's) have relied on typical situations where resources are scarce (Reilly and Knight, 2007). Work is volunteer -driven despite the fact that there should be a local responsibility for keeping up to date with coaching techniques, and current world performance standards and the requirements of memberships is significant (Seguin, Teed and O Reilly, 2005; Berrett and Slack, 2001).

Archetype approaches are fine and well being, but due to the changing face of sport where adaptability and innovation are important to NSO's, particularly in the realm of Olympic sports where funding is based on results (O Reilly and 
Knight, 2007) there could be concerns with patterns of archetypal change (Kiklulis et al, 1995). In short, whether organisational structure and operations that are more susceptible or resistant to change (Kikulis et al, 1995)? Some organisational elements may be particularly difficult to change because they embody deeply held value, yet it may be these specifically that need changing in order to signal the purpose and seriousness of change (Schein, 1985; Kanter, 1984). Greenwood and Hinings (1988) theorised this approach similar to that of Pettigrew (1985) and Dawson (1996) in presenting a model for the dynamics of organisational change (Figure 3). This model suggests that the archetype adopted has separation from the three areas that may influence it, or the symbiotic bounding by the change process. As with the model of Dawson (1996), this model does not convey the idea of the dynamics of change over time (Nelson, 2003) and subsequently this is essential for National Governing Bodies in sport who are developing radically day by day to government and also there lead authorities in sport such the International Olympic funding Committee.

As O Reilly and Knight (2007) have indicated there is and ever increasing demand on National Governing Bodies/ NSO's to produce results in this area in an environment where funding is spouse. Because of this demand once what has traditionally been regarded as not-for-profit service sector area of sport has to become more effective in all areas moving outside of its status quo/ equilibrium. Laughlin (1991) indicates that it is the environmental disturbances that can consequently cause a sports organisation to move out of its equilibrium. Laughlin (1991) goes on further to suggest that the organisation will either absorb the disturbance or maintain its previous equilibrium or, as a result of shift its design archetype, sub system elements and interpretive schemes and develop a new equilibrium. This forms the basis to provide a typology describing the complexity of organisational change (Skinner, Stewart \& Edwards, 1999).

\subsection{Typology Organisational Change in Sports Organisations}

Laughlins (1991) Suggested that an organisation will change only when disturbed, kicked or forced into doing something. Once the organisation undergoes an environmental disturbance the type of change can either be first or second order change (see table 1) (Skinner, Stewart \& Edwards, 1999).

Laughlin (1991) draws upon work of Smith (1982) and Robb (1988) to put forward the notion as morphastasis (first order) or morphogensis (second order) change

According to Laughlin (1991) an organisation is assumed to be in a state of inertia and is operating in equilibrium before disturbance arrives. However what is clearly apparent is that NSO's (not-for-profit) have generally comprised of heterogeneous groups, from what has historically being renowned from small local associations managed by few volunteers. But because of the environmental disturbances that a sport has had and is still going through these volunteers are now becoming accountable to chief executives. This then could be argued that not for profit NSO's have to now operate in similar environments as the profit world, and as such require managerial tools and tactics that are specific to their area (O Reilly and Knight, 2007).

This reorientation which is in the first order of Gray, Walters and Bebbington and Thompson's (1995) model is the result of a disturbance that cannot be rebutted but has to be accepted or internalised into the workings of the organisation (Skinner, Stewart and Edwards, 1999) Gray et al (1995) theorise that in this instance that the "real heart" of the organisations is basically unaffected. In other words change is effectively resisted by the volunteers with in the organisation and they wish to stay in inertia. So with in the sports organisation creates conflict. Gray et al (1995) further argues that Laughlin's (1991) model is too rigid. It does not allow for that conflict, ambiguity or contradiction. Specifically, Gray et. al (1995) criticised the models inability to recognise disturbances a priori (i.e., in advance of the event occurring), to assess what constitutes real morphogenetic change the second order of change.

Examining archetypes Amis, Slack and Hinnings (2002) found that organisations with members in amateur sports who held values congruent with the prescribed changes engaged in the transition process, while those members who opposed the changes only superficially conformed.

The concept of design archtype stipulates that structure and expression of values which serve particular interests (Kikulis et al, 1995). Greenwood and Hinnings (1988,1993), Laughlin (1991), Nadler and Tushman (1989), Ranson et al (1980, and Tushman and Romanelli (185) have all in their own way argued that the difficulty in reorientation or organisational change is the attachment of value established organisations. Thus movement between archetype is difficult (KIkulis et al, 1995). What clearly must be noted is that for such change to take place they must abandon their strong values towards the institution. In the case of amateur sport organisations, it has been argued that voluntary led decision making structures symbolise the legitimate, rational way to organise this sector of sport (Kikulis et al, 1995). By embracing this process it may reduce the bureaucratisation in the professionalisation of sport, Slack (1985) found that while bureaucratic characteristics existed within sport organisations, these did not all emerge because of this.

\subsection{Transitional period moving from Amateurism to Professionalism}

Slacks (1985) study focused on the Canadian Amateur Swimming Association and it showed that during the early stages of its development the only bureaucratic manifestations exhibited by voluntary sport organisations were a functional division of labour and a control system which took the form of a set of rules and regulations. As the organisations grew, 
so did the complexity of manifestations (Ferkins et al, 2005). These findings go some way in describing the changing nature of sport organisations as they exhibit aspects of a bureaucracy and the nature of change that is a piece meal approach according to internal external environmental disturbances.

Subsequent studies have focused on the professionalisation of sport organisations that have moved from entities administered by volunteers to those managed predominantly by paid staff (Shilbury, 2001: 53). Evidence for this assertion comes from Slack and Hinnings (1992) in a study examining change in Canadian National Sport Organisations. It was noted a trend towards a professional bureaucratically structured design, but reluctance on behalf of the volunteers to cede decision making control to paid staff. The research showed that such change appeared to challenge the traditional volunteer based culture of these organisations. This was further supported by Shilbury (2001) who concluded that reluctance on behalf of volunteers to cede decision making control has been the short comings of the professionalisation process of sport.

What is clearly evident is that there needs to be a clearer understanding of the roles and functions of boards of directors in sports organisations to better understand the dynamics of this change process (Ferkins et al, 2005). Furthermore a better understanding of this dynamisms needs to be understood and its impact on the development of sports. It could be argued because of this bureaucracy, resistance to change decision making gets slowed down, which in some cases reflects the future of sport and where it could be today. One such sport in the United Kingdom could be the Amateur Swimming Association.

The Amateur Swimming Association is the English National Governing Body for swimming, diving, water polo, open water and synchronised swimming (Amateur Swimming Association (ASA), 2007). The ASA supports 1,600 affiliated swimming clubs through a National/ Regional/ County Structure (Figure, 4)

The ASA Council commissioned a review of the membership of the specific aim of answering the questions "what is a member"? The responsibility for conducting that review was delegated, by Council Regionalisation's Project Board (RPB)". The report was written by members of the board who have striven to maintain their independence and accessibility to whole of sport (ASA Committee, 2004). This was very similar in the research conducted by Kikulis et al (1995) where the Canadian National Sports Organisations made adaptations in their programmes in an effort to enhance their effectiveness of the delivery of amateur sport services. Slack (1985), highlighted, though there was a general conformity to make amateur sport more efficient and effective, they still held bureaucratic characteristics which in essence may hold up the development of the sport? This then contravenes what government has set about in the United Kingdom (UK) in the development of regionalisation, where they stipulate by doing so will allow sport to be well managed to the success in world competitions (ASA, 2004).

What is clearly evident that this was marked as movement from sport and the ASA from a simply structured and volunteered-governed organisations towards a more professional and bureaucratic form (Kikulis et al, 1995). What now can clearly be established in the United Kingdom is due to the sport of swimming becoming a complex organisation, has this inhibited or assisted the sport developing? More over because of the change in design archetypes, do NSO's still carry the core values and expressions of originally volunteered formed organisations (Kikulis et al, 1995). Many theorists have argued this (Hoye and Cuskelly, 2003, Kikulis et al, 1995, Greenwood and Hinnings, 1993 \& 1988, Laughlin, 1991; Nadler and Tushman, 1989; Tushman and Romanelli, 1985; Ranson et al, 1980). To achieve such a change requires the abandoning existing values for which they hold. In the case of the Amateur Swimming Association, it has been argued that voluntary-led decision making structures symbolise the legitimate rational way to organise decision making in this sector (Kikulis et al, 1995).

Therefore this study will look at the impact that these changes.

\section{Research Analysis}

The method that was employed to unearth such findings was a quantitative approach. The organisations that were chosen operate in a highly knowledgeable and intensive environment (OReilly and Knight, 2007).Thirty Swimming Clubs were randomly selected to participate in this study (Fink, Pastore and Riemer,2003). This number ensured that the sample proportion would be within 0.05 of the population proportion, with a $95 \%$ level of confidence (Issac \& Michael, 1984).

Following a similar approach by Fraenkel and Wallen (2000), where they used an intact cluster associated to athletic departments. Executive committee members (Head Coaches, Chairman's and club secretaries, etc) from each of the thirty clubs they were sent a covering letter explaining the aim of the research project, a statement ensuring confidentiality of their responses. Instruction of completing the questionnaire, the contact details of the researcher (Hoye, 2004) and a self- administered questionnaire. This type of method was used by Herman and Renz (1997) who determined it to be a reliable and valid measure on organisational performance.

The data collection involved the distribution of the self administered questionnaires to a specific board executive $(N=30)$ on the committees of the swimming clubs. This was a very similar approach adopted by Hoye (2004) \& Hoye and 
Cuskelly (2003) where they distributed self administered questionnaires to all the board members $(N=50)$ of a selected number of voluntary sports organisations. The data that was being collected (as will be seen by the results) identified that a number of the clubs are still going through a change period (i.e. real time data analysis). This method was employed also by Kikulis et al (1995) \& Pettigrew (1987) where they felt it was important to conduct a real time longitudinal study to best capture the variety or organisation design patterns of change.

\subsection{Method of Analysis}

The method of analysis used to identify if changes with in National Governing body of swimming with in the United Kingdom has had an impact on structural change with in the foundations of the sport (clubs that hold the sport together and develop the swimmers from the grass roots level) was the Statistical package for the social sciences (SPSS 13.0). All thirty respondent questionnaires from the clubs that were randomly selected were inputted and analysed through this method. The main descriptive and inferential findings are discussed in the results section.

\section{Analysis Findings}

The descriptive statistics (i.e. means, frequencies) are used to describe the main variables of interest (Fink, Pastore and Riemer, 2003). Then a one way anova test was conducted along with a non-parametric analysis of variance (Kruskal-Wallsis test) of mean scores (Hoye and Cuskelly, 2003) of the year the clubs were formed impacted their Swim 21 (National Accreditation of Quality and Change) and also employing (paid) staffs.

Table 2 highlights the year the swimming clubs were formed. With a valid per cent of $100(\mathrm{~N}=30)$, what is clearly evident that most clubs were formed/ founded between 1966-1975 which accounts for 30\% of the clubs used in the research.

The histogram in figure 5 supports table of the years the clubs were founded because it is demonstrating that standard deviation from the mean is $3.34(.9>.5)$. This indicates that the normal distribution of the curve is wider than normal. Because of this it determines which of non-parametric and parametric tests will be used at the $95 \%$ level.

Figure 6 displays the means of the clubs who have a paid employee with in their organisation. A total of 18 of the 30 clubs used in the research have a paid person. Who tended to be the head coach, this was at $60 \%$. This indicates that a further $40 \%$ still do not have paid positions with in their organisations and work mainly on a voluntary basis.

Table 3 highlights that most of the clubs that were identified had management committees $(27=90 \%)$. What is clearly evident from this response rate that clubs do rely heavily on this type of voluntary management with in their organisation and environment that they operate in at present?

Using a one way anova statistical test see if there is relationship between the year a club was formed impacted their decision to have paid employees or not the a result displayed in table demonstrates a difference of at $<0.05=95 \%$ of 0.41 displaying there was no relationship because of the year they were formed.

Using a Kruskal Wallis Test figure 7 shows from 1971-1990 $=53 \%(\mathrm{P}=0.095>0.05)$ have or are working towards the Swim 21 accreditation. This indicates that the clubs that have been formed for approximately $30+$ years are going through or have gone through organisational change over the last three decades.

Table 5 demonstrates that though the management committees are made up of volunteers there is no relationship between the choice of having paid employees $(\mathrm{P}=0.20>0.05)$ or a club work towards or having Swim 21 accreditation.

In recent years change has become an increasingly prevalent feature of organisational life (Amis, Slack \& Hinings, 2004). Concomitantly, and not surprisingly, the study of transitions between organisations has become a popular topic for academic research (Slack et al, 2002,Kikulis, 2000, Hinings, Thibault, Slack, \& Kikulis, 1996, Kikulis, Slack \& Hinings, 1992,1995a, 1995b; Macintosh \& Whitson, 1990; Slack, T \& Hinings, 1992 \& 1994). To date a lot of this research has focused on the structural change, but very little has focused on the impact it has had on those who serve as foundation to National Governing Bodies in sport. And incrementally what impact has this radical transformation had on those who servos the sport (Kikulis et al, 1995, Stevens and Slack, 1995)?

What is clearly evident that change has not had a great deal of impact to those who servos the sport. Some of the key arguments developed through this paper were, what impact would change have from Amateur (volunteerism) to be more professionalised (Hoye, 2004, Skinner, Stewart and Edwards, 1999, Kikulis et al, 1995)? And can volunteers work in harmony with paid employees (Inglis, 1997, Thibault, Slack \& Hinings, 1991)? Also can those who have, what Kikulis (1995), Schein, (1985) \& Kanter, (1984) call "deeply held values" from years of being amateur in operation cope with systems of change.

There is now evidence to suggest because of NGB's changing and adopting a new structure it has not inhibited those who hold the foundation of and development of the sport. Figure 6 demonstrates that most swimming clubs still operate collectively with paid staff, e.g. Head Coaches and a voluntary management committee. This is further demonstrated in table 3 where most of the clubs researched are made up of volunteers $(\mathrm{N}=27=90 \%)$. So though it has been stated by 
Taylor and Ho (2005) that they must change, what is clearly apparent they can change? Arguably, before the introduction of paid staff, the management committee would be and in some cases is still the leader in most of the clubs explored in this study (Hoye, 2004). But any change must be incremental and also be symbiotic in this process. Taylor and Ho (2005) go onto further describe this as a boardroom archetype and is still held with in a volunteer controlled hierarchy, but also is supported by professional staff (Head Coach). This would then reinforce as Seguin, Teed and O Reilly, (2005) and Berrett and Slack (2001) suggest that the club and the head coach can keep on developing and staying abreast of the latest coaching techniques and swimming development areas such as Swim 21 accreditation. This would be in some cases a model of change similar to that of Pettigrews (1985) (Figure 1) model where they want to be part of dynamic change, which is not the models presented by Dawson (1996) and Greenwood and Hinings (1988).

What has clearly been demonstrated from this research that change in structures where organisations have to work in harmony with paid employees that the board members are embracing this, though some areas are still slow in movement? All clubs have to move towards a change in the adoption to volunteer roles in achieving Swim 21 status with in the sport, a quality and organisational change award to improve the future of swimming. Which Pettigrews (1985) model demonstrates that are components that convey the idea of movement and variability which precede outcomes (Nelson, 2003). This is also what Laughlin (1991) puts down to as a disturbance or having to now do something different. Laughlins (1991) model (Table 1) in the inertia stage is clearly apparent and relevant to those clubs formed before 1971 (figure 7). Where as a large number of clubs that were founded from $1971-1990(53 \%)$ or going through that typology of change morphostatic (first order) and morphogentic (second order). Those that have been founded through the era 1981-1990 have achieved that level and now hold the accredited award.

It seems to be prevalent with in the sport that is those pre 1971 still hold what Gray et al (1995) describes as the deeply held values, but he then argues that Laughlins (1991) model is to rigid? But it could be argued that with in sport it forms the basis for this research similar to Pettigrews (1985) outcome variability model. So it is relevant to the sport of swimming because of its structure with in the United Kingdom. Also as Skinner et al (1999) states the model is useful as it provides a way of putting particular changes (Swim 21 accreditation) into conceptual categories or compartments. Though his model is useful it must be identified that because of the emergence of what Bergquist (1993) "post modern management structures" organisations adopting Laughlin's (1991) model needed to be a little bit more flexible. This implies that to achieve Swim 21 accreditation a number of quite different changes could be occurring at any one time in the organisation, each influencing the other and leading to turbulent backwashes (Skinner et al, 1999) therefore it could be argued that this is similar to Dawsons (1996) (figure 2) framework. However to deal with these backwashes, it must be noted that the possibility of the application of Llewellyns (1994) model on boundary management along with working in conjunction of Laughlins (1991) model of the typology of change would be useful. Llewellyns first addresses the boundaries of closed systems and suggest that the boundaries of these systems are relatively impermeable to the forces of their surrounding environments (Skinner et al, 1999). Cooper (1990) likens this to a container of holding things in.

These two models would be clearly be suitable in working together because of the environmental disturbances that swimming with in the United Kingdom has and are going through. Because of the distinct changes the regions of British Swimming are going through it is essential that the organisations that hold this together react and adopt change also. As at present most post modern swimming clubs (figure 7) have adopted this change, (Laughlins, 1991, second and third). However pre 1971 there is still is some resistance.

\subsection{The Evolutionary Change in a competitive environment}

Never before have sport organisation had to change and work in an ever changing competitive environment (Davakos, 2006). In such an environment, only the best prepared organisations will survive and continue to prosper. What is clearly evident today that swimming with in the United Kingdom has gone through and is still going through change with in the environment that it operates? This has been clearly seen that the hierarchy of the sport (NGB) over the last two/ three decades has had to adopt change and this has then filtered down to what Skinner et al (1999) refers to as the grass roots level or foundation.

Models of change such as Dawsons (1996),Laughlins (1991), Greenwood and Hinnings (1988) and Pettigrews (1985) can in essence help clubs to understand how to deal with change or the factors that affect them. Each model identifies the clear determinants of change and most importantly some of the factors that will or possibly affect them in the future. Also Nelson (2003) has indicated that change cannot be relied upon to occur at a steady state any longer and that all organisations not just in sport must be aware of this. She further goes onto to express that from a viewpoint, even for sports clubs/ organisations to maintain viability they need to incrementally change in what Tushman, Newman and Romanelli (1986) convergent change.

\section{References}

Adzies, I. (1979) Organisational passages: Diagnosing and treating life cycle problems of organisations. Organisations 
Dynamics, 8, 3-25

Amateur Swimming Association (2007) The History of the Amateur swimming Association. Accessed, 15 ${ }^{\text {th }}$ May, $2.30 \mathrm{pm}$, www.britishswimming.org

Amateur Swimming Association Committee (2004) Membership Review/ Regionalisation. Accessed, 15 ${ }^{\text {th }}$ May, $2.35 \mathrm{pm}$, www.britishswimming.org

Amis, J., Slack, T. \& Hinings, C.R. (2004) Strategic Change and the Role of Interests, Power and Organisational Capacity, Journal of Sport Management, 18,(2) 158-198

Amis, J., Slack, T. and Hinings, C.R. (2002) Values and organisational change, The Journal of Applied Behavioural Science, (38), 4, 436-466

Bergquist, W. (1993) The post-modern. organisation; Mastering the art of irreversible change. San Francisco; Jossey-Bass

Berrett, T. and Slack, T. (2001) A Framework for the analysis of strategic approaches employed by non-profit sport organisations in seeking corporate sponsorship, Sport Management Review (4) 21-45

Cameron, K.S., \& Whetten, D.A. (1983a). Models of organisational life cycle: Application to higher education. Review of Higher education, 6, 269-299

Chelladurai, P. (1999) Human Resource Management in Sport and Recreation, Champaign IL, Human Kinetics

Child, J. and Smith, C. (1987) The context and process of organisational transformation-Cadbury Limited in its Sector. Journal of Management Studies, 24, 565-93

Cooper, R. (1990) Organisations/disorganisations. In J. Hassard \& D. Pym (eds), The Theory and philosophy of organisations (pp167-197) London: Routledge

Dawson, P. (1996) Beyond convential change models: a processual perspective” In Nelson, L (2003) A case study in organisational change: implications for theory. The Learning organisation

Davakos, H. (2006) An integral part of strategic planning for sport organisations: training employees. International Journal of Sport Management and Marketing 1 (4) 390-397

Ferkins, L., Shilbury, D. \& Mcdonald, G. (2005, i) The Role of the Board in Building Strategic Capability: Towards and Integrated Model of Sport Governance Research. Sport Management Review (8) 195-225

Ferkins, L., Shilbury, D. \& Mcdonald, G. (2005, ii) The Role of the Board in Building Strategic Capability: Towards and Integrated Model of Sport Governance Research. Sport Management Review (8) 195-225

Fink, J.S. \& Pastore, D.L. (2003) Managing Employee Diversity: Perceived Practices and Organisational Outcomes in NCAA Division III Athletic Departments, Sport Management Review, 6, 147-168

Fomburn, C.J. (1992) Turning Points, MCgraw Hill, New York

Forbes, D.P. \& Milliken, F.J. (1999) Cognition and corporate governance: Understanding boards of directors as strategic decision making groups. Academy of Management Review, 24, 489-505

Fraenkel, J.R., \& Wallen, N.E. (2000). How to design and evaluate research in education. New York: Mcgraw Hill

Gopinath, C., Siciliano, J.1. \& Murray, R.L. (1994) Changing Role of the Board of Directors': In search of a new strategic identity? Mid Atlantic Journal of Business 30 (2) 175-183

Gray, G., Walters., Bebbington, J., and Thompson, I. (1995) The greening of enterprise; An exploration of the (non) role of environmental accounting and environmental accountants in organisational change. Critical perspectives on Accounting, G, 211-239

Greenwood, R and Hinnings, C.R. (1988) Organisational design types, tracks and the dynamics of strategic change. Organisation Studies, (, (3) 293-316

Greenwood, R and Hinnings C.R (1993) Understanding Strategic change; The contribution to archetypes. Academy of Management Journal , 36, 1052-81

Herman,R.D \& Renz, D.O (1997) Multiple constituencies and social construction of nonprofit organisational effectiveness. Nonprofit and Voluntary Sector Quarterly, 26, 185-206

Hinings,C.R., Thibualt, L., Slack, T., \& Kikulis, L.M, (1996) Values and Organisational Structure. Human Relations, 49, $885-916$

Hinings, C.R \& Greenwood, R (1988) The dynamics of strategic change. Oxford: Basil Blackwell

Hoye, R, (2004) Leader-Member Exchanges and Board Performance of Voluntary Sports Organisations. Nonprofit 
Management and Leadership, 15 (1) 55-67

Hoye, R., and Cuskelly, G (2003) Board - Executive Relationships within Voluntary Sport Organisations, Sports Management Review, 6, 53-74

Hoye, R., and Stewart, R., (2002) Power and Organisational Change: The Case of Melbourne Women's Hockey Association 1995-1998. Sporting Traditions, 18 (2) 47-65

Hoys, R., \& Auld, C (2001) Measuring board performance within voluntary sport organisations. Australian Journal of Volunteering, 6 (2) 53-74

Issac, S/., \& Michael, W.B (1984) Handbook in Research in organisations and evaluation. San Diego CA: Edits Publishers

Kanter, R.M (1984) Managing transition in organisational culture: the case of participative management ay Honeywell. In Kimberley, J.R and Quinn, R.E (Eds) Managing Organisational Transition. Homewood, Ill: Irwin, 195-217

Kanter, R.M (1984) Managing transitions in organisational culture; the case of participative management at Honeywell, IN Kimberley, J.R and Quinn, R.E (eds) Managing Organisational Transitions. Homewood,IL; Irwin, 195-217

Kanter, R.M (1983) The Change Masters. New York: Simon and Schuster

Kimberley, J.R (1987) The life cycle analogy and the study of organisations: Introduction, In Kimberley, J.R \& Miles, R.H (eds) The Organisational Life cycle (pp 1-14). San Francisco: Jossey-Bass

Kikulis, L.M (2000) Continuity and Change in Governance and Decision Manking in National Sport Organisations: Institutional explanations. Journal of Sport Management, 14, 293-320

Kikulis, L.M., Slack, T, \& Hinings, C.R. (1995a) Sector specific patterns of organisational design change. Journal of Management Studies, 32 (1) 65-95

Kikulis,L.M, Slack., T and Hinings, B (1995b) Does Decision Making Make a Difference? Patterns of Change Within National Sport Organisations. Journal of Management Studies, 9, 273-299

Kikulis, L.M., Slack, T, \& Hinings, C.R. (1995c) Sector specific patterns of organisational design change. Journal of Management Studies, 32 (1) 67-100

Kikulis, L.M., Slack, T, \& Hinings, B. (1995d) Toward an Understanding of the Role of Agency Choice in the Changing Structure of Canada's National Sport Organisations. Journal of Sport Management, 9, 135-152

Laios, A, (1995) School versus non-school sports; structure, organisation and function in Greece, Europe and the USA, International Journal of Educational Management, 9, 1 pg 4-9

Laughlin, R.C (1991) Environmental disturbances and organisational transitions and transformations; Some alternative models. Organisation Studies, 12, 209-232

Llewellyn, S. (1994) Managing the boundary; How accounting is implicated in maintaining the organisation. In Skinner, J, Stewart, \& Edwards, A (eds) Amateurism to Professionalism: Modelling Organisational Change in Sport Organisations. (pp 173-192) Sport Management Review

Macintosh, D \& Whitson, D.J (1990). The game planners transforming Canada's sport system. Montreal \& Kingston: McGill-Queen University Press

Miller, D, (1990) The Icarus paradox: How exceptional companies bring about their own downfall. New York, Harper Collins

Miller-Millese, J.L (2003) Understanding the behaviour of non-profit boards of directors: A theory based approach. Non-profit and Voluntary Sector Quarterly, 32, 521-547

Miller, J.L (2002) The board as a monitor of organisational activity: The applicability of agency theory to non-profit boards. Non-profit Management and Leadership, 12, 429-450

Nalder, D.A and Tushman, M.L (1989) Organisational frame bending: principles for managing reorientation. Academy of Management Executive, 3, 194-204

Nelson, L (2003) A case study in organisational change: implications for theory. The learning Organisation, 10 (1) $18-30$

Oliver,C (1991) Strategic Responses to institutional processes, Academy of Management Review, 16, 145-179

Ranson, S, Hinnings, C.R., Greenwood, R and Walsh, K (1980) Value preferences and tensions in the organisation of local government. In Dunkerley, D and Salaman, G (eds). The international Yearbook of Organisational Studies. London: Routledge and Kegan Paul 197-221

O'Reilly, N.J and Knight, P (2007) Knowledge management best practices in national sport organisations, International 
Journal Sport Management and Marketing (2), 3, 264-273

Rowley, J (2004) Researching people and Organisations, Library Management, 15 (4) 208-214

Peters, T (1990) Get innovative or get dead, California Management review, 33, 9-26

Pettigrew, A (1987) Context and action in the transformation of the firm. Journal of Management Studies, 24, 649-670

Pettigrew, A (1985) A wakening giant: continuity and change in ICI, Basil Blackwell, Oxford In Nelson, L (eds) A Case Study in Organisational Change. The Learning Organisation.

Schein, E (1985) Organisational Culture and Leadership. San Francisco: Jossey-Bass

Seguin, B., Teed, K. and O Reilly, N (2005) National sport organisations and sponsorship; an identification of best practices' International journal of sport Management and marketing (1) , 2, 69-92

Shilbury, D (2001) Examining board member roles, functions and influence: A study of Victorian sporting organisations. International Journal of Sport Management, 2, 253-281

Skinner, J., Stewart, B. \& Edwards, A (1999) Amateurism to Professionalism: Modelling Organisational Change in Sporting Organisations, Sport Management Review, (2) 173-192

Slack, T (1985) The beaucratisation of a voluntary sports organisation, International review for the Sociology of sport, (20) $145-166$

Slack, T and Hinnings, B(1992) Understanding Change in National Sport Organisations; an integration of theoretical perspectives; Journal of Sport Management. (6), 114--132

Slack, T., \& Hinnings, B (1994) Institutional Pressures and Isomorphic Change: An Empirical Test, Organisation Studies 15 (6) 803-827

Slack, T, (1997) Change in Sports Organisations, Understanding Sport Organisations. Champaign IL, Human Kinetics, $\operatorname{pg} 211-217$

Smith, K.K (1982) Philosophical problems in thinking about organisational change. In Goodman, P.S \& Associates (eds) Change in organisations 316-374 San Francisco: Jossey_Bass

Stevens, J.A \& Slack, T. (1998) Integrating social action and structural constraints. International Review for the Sociology of Sport, 33, 143-154

Robb, F.F (1988) Morphostasis and morphogenesis: Contexts of participative design inquiry in the design of systems of learning and human development. Unpublished Discussion paper. University of Edinburgh

Taylor, T., and Ho, C (2005) Global Human Resource Management Influences on Local Sport Organisations. International Journal of Sport Management and Marketing (1) 1,2, 110-120Thibault, L., Slack, T., and Hinnings, B (1991) Professionalism, Structures and Systems: the impact of Professional Staff on Voluntary Sport Organisations. International Review for the Sociology of Sport, 26 (2), 83-97

Tushman, M.L and Romanelli, E (1985) Organisational Evolution; a metamorphosis model of convergence and reorientation. In Cummings, L.L and Staw, B.M (eds) Research in Organisational Behaviour, 7, Greenwich, Conn: Jai Press, 171-222

Zucker, L.G (1989) Combining institutional theory and population ecology: No legitimacy, no history. American Sociological Review, 54, 542-545

Table 1. Laughlins (1991) Typology of Organisational Change (adapted from Gray, Walters, Bebbington and Thompson, 1995)

\begin{tabular}{|l|l|}
\hline No Change & "Inertia" \\
\hline First Order Change & $(1)$ “Rebuttal" \\
\cline { 2 - 2 } (Morphostatic) & $(2)$ "Reorientation" \\
\hline Second Order Change & $(1)$ "Colonisation" \\
\cline { 2 - 2 } (Morphogenetic) & $(2)$ "Evolution" \\
\hline
\end{tabular}


Table 2. Year in Which the Club was Founded

\begin{tabular}{|l|l|l|l|l|l|}
\hline \multicolumn{2}{|l|}{} & & & & \\
\hline \multicolumn{2}{|l|}{} & Frequency & Percent & Valid Percent & $\begin{array}{l}\text { Cumulative } \\
\text { Percent }\end{array}$ \\
\hline Valid & $1940-1945$ & 4 & 13.3 & 13.3 & 13.3 \\
\hline & $1956-1960$ & 1 & 3.3 & 3.3 & 16.7 \\
\hline & $1961-1965$ & 1 & 3.3 & 3.3 & 20.0 \\
\hline & $1966-1970$ & 3 & 10.0 & 10.0 & 30.0 \\
\hline & $1971-1975$ & 6 & 20.0 & 20.0 & 50.0 \\
\hline & $1976-1980$ & 2 & 6.7 & 6.7 & 56.7 \\
\hline & $1981-1985$ & 4 & 13.3 & 13.3 & 70.0 \\
\hline & $1986-1990$ & 4 & 13.3 & 13.3 & 83.3 \\
\hline & $1991-1995$ & 1 & 3.3 & 3.3 & 86.7 \\
\hline & $1996-2000$ & 4 & 13.3 & 13.3 & 100.0 \\
\hline & Total & 30 & 100.0 & 100.0 & \\
\hline
\end{tabular}

Table 3. Clubs with management committees formed made up of volunteers

\begin{tabular}{|l|l|l|l|l|l|}
\hline \multicolumn{2}{|c|}{} & Frequency & Percent & Valid Percent & $\begin{array}{l}\text { Cumulative } \\
\text { Percent }\end{array}$ \\
\hline \multirow{3}{*}{ Valid } & Yes & 27 & 90.0 & 90.0 & 90.0 \\
\cline { 2 - 6 } & No & 3 & 10.0 & 10.0 & 100.0 \\
\cline { 2 - 6 } & Total & 30 & 100.0 & 100.0 & \\
\hline
\end{tabular}

Table 4. Year in which the club was formed impacting if the organisation has paid employee's.

Year in Which the Club was founded

\begin{tabular}{|l|l|l|l|l|l|}
\hline & $\begin{array}{l}\text { Sum of } \\
\text { Squares }\end{array}$ & df & Mean Square & F & Sig. \\
\hline Between Groups & 8.022 & 1 & 8.022 & .712 & .406 \\
\hline Within Groups & 315.444 & 28 & 11.266 & & \\
\hline Total & 323.467 & 29 & & & \\
\hline
\end{tabular}

Table 5. The Management Committee mad of Volunteers impacting decisions of paying employees and undertaking Swim 21 accreditation

a Kruskal Wallis Test

\begin{tabular}{|l|l|l|}
\hline & $\begin{array}{l}\text { Paid Positions } \\
\text { with in the club }\end{array}$ & $\begin{array}{l}\text { Hold Swim 21 } \\
\text { Accreditation }\end{array}$ \\
\hline Chi-Square & 1.645 & .264 \\
\hline df & 1 & 1 \\
\hline Asymp. Sig. & .200 & .607 \\
\hline
\end{tabular}

b Grouping Variable: Management Committee Made up of Volunteers 

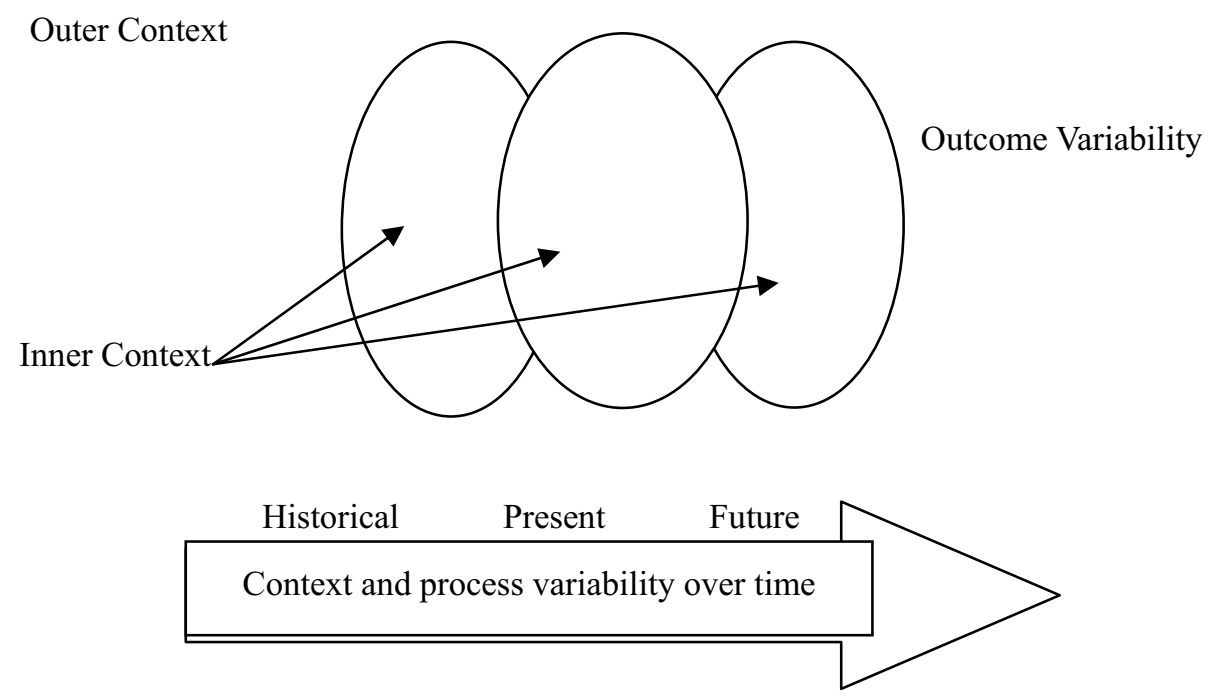

Figure 1 Components of Analysis: context and process (Adapted from Pettigrew (1985) in Nelson 2003)

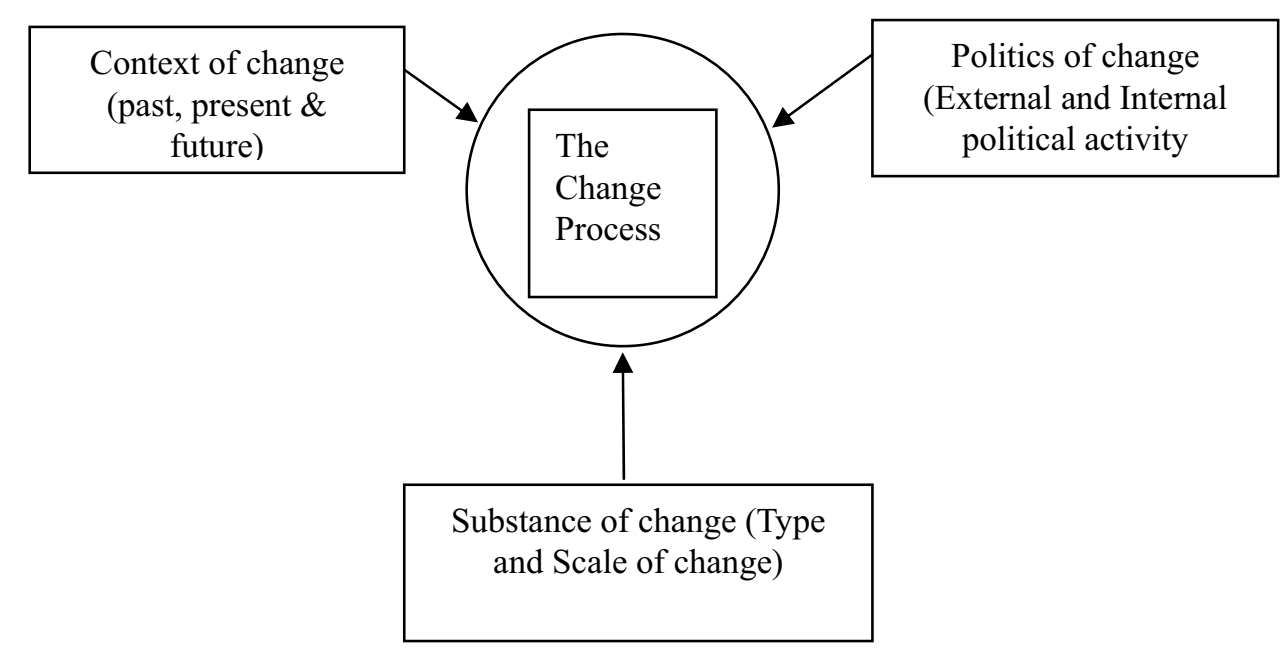

Figure 2 Determinants of Organisational Change (Adapted from Dawson, 1996)

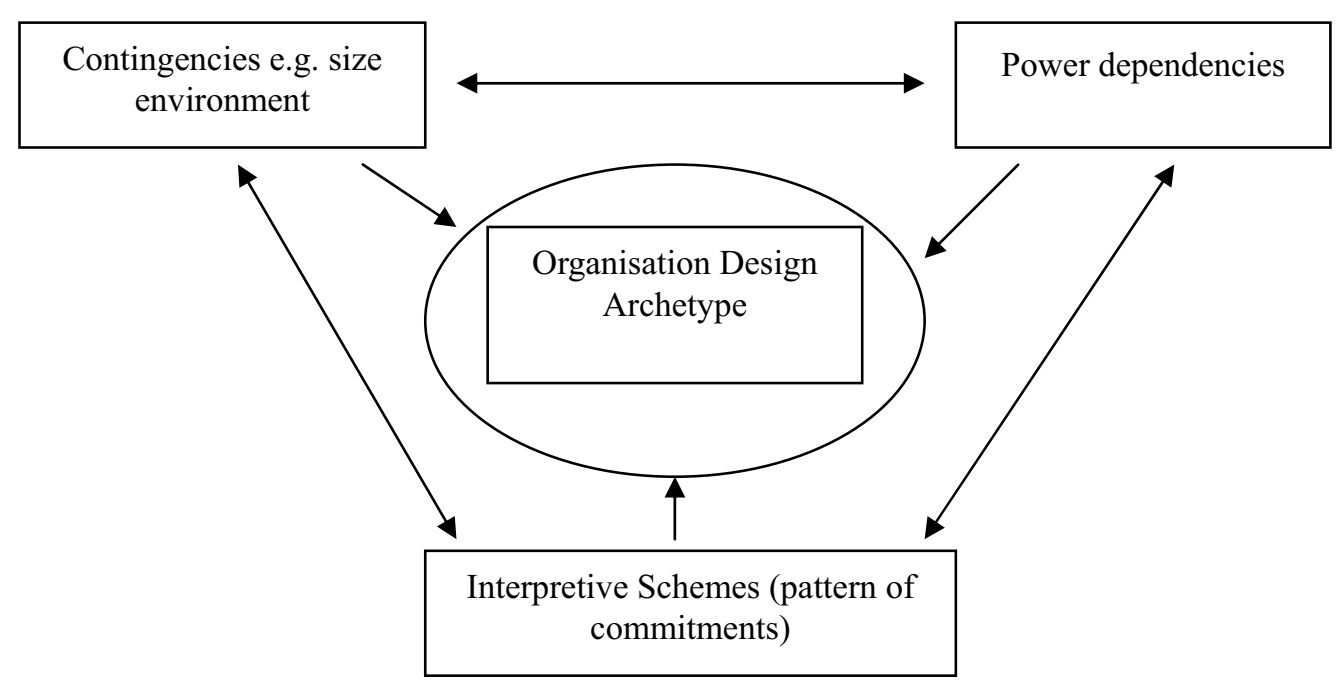

Figure 3. The dynamics of Organisational Change (Adapted from Greenwood and Hinings, 1988) 


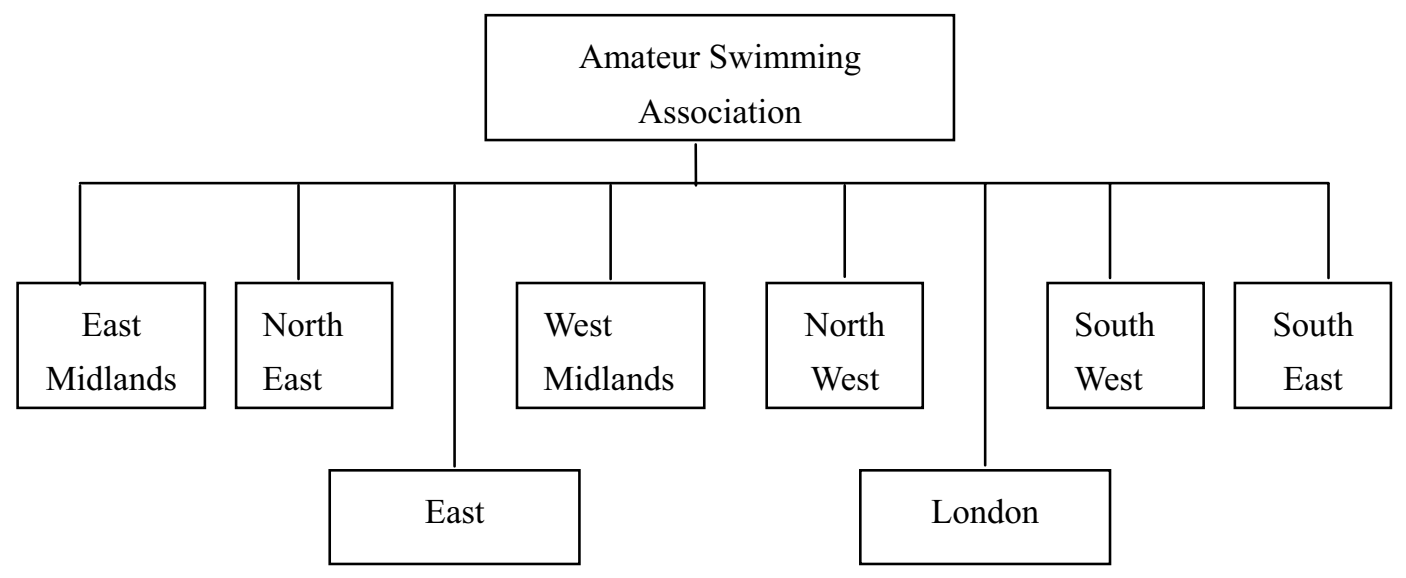

Figure 4. Amateur Swimming Association Regional Structure (adapted from Institute of Swimming, 2006)

\section{Histogram}

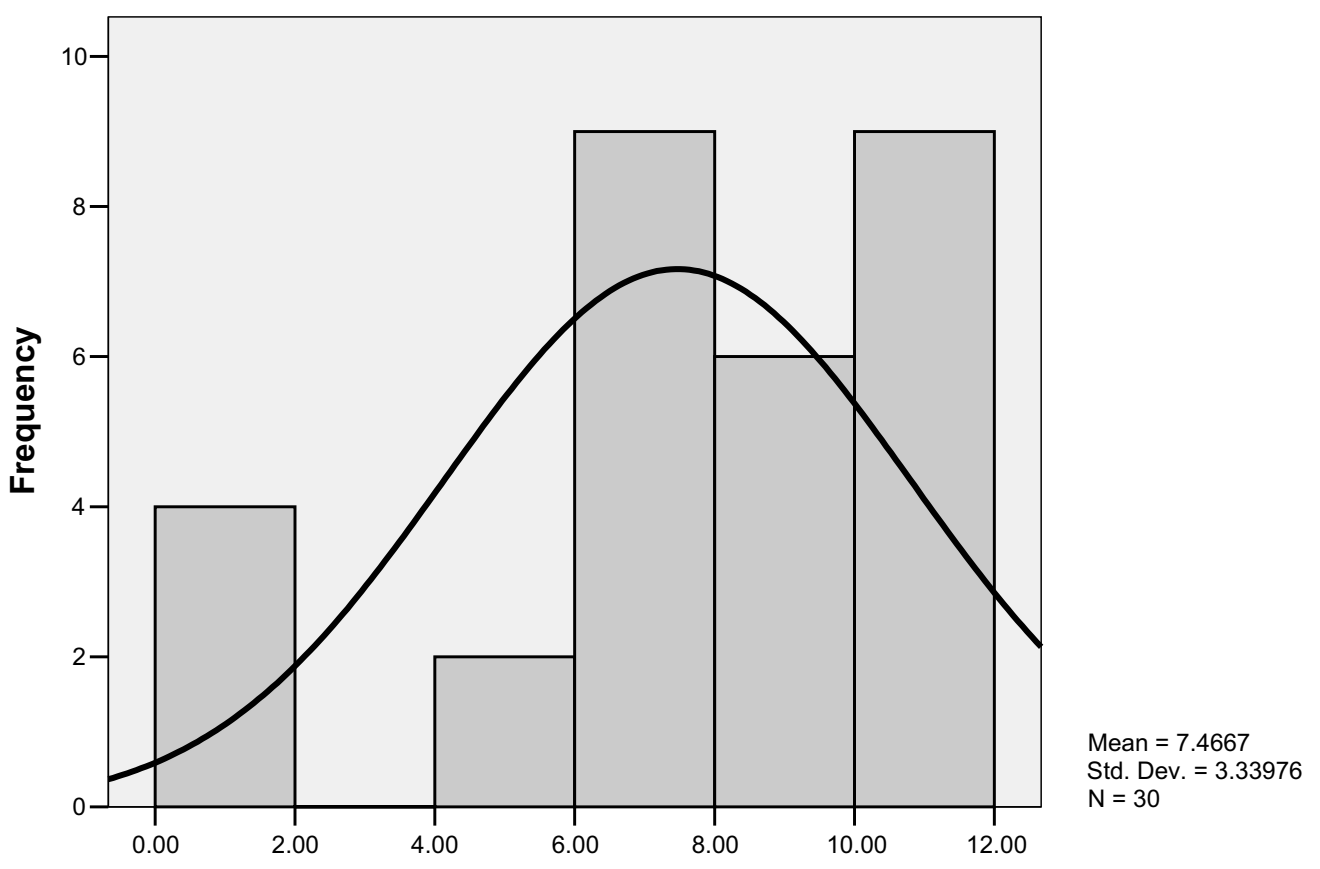

Figure 5. Year in Which the Club was Founded 


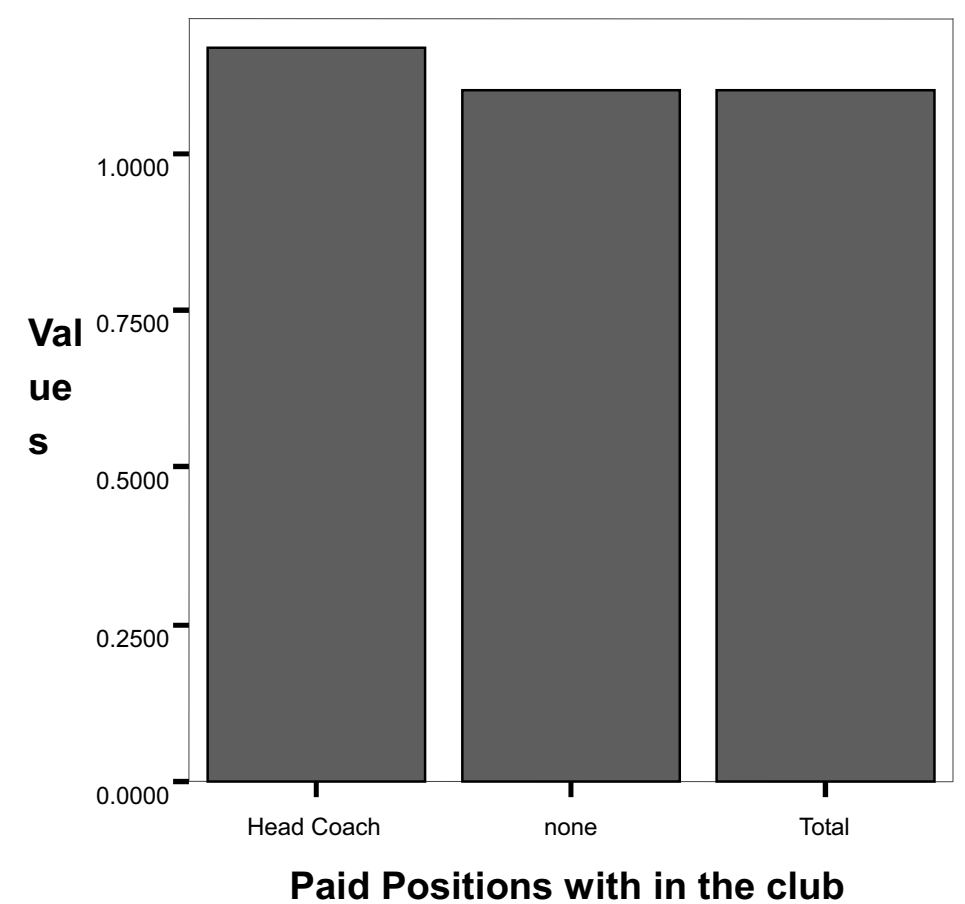

Figure 6. The Year Management Committee was formed and The Number of paid positions with in the club

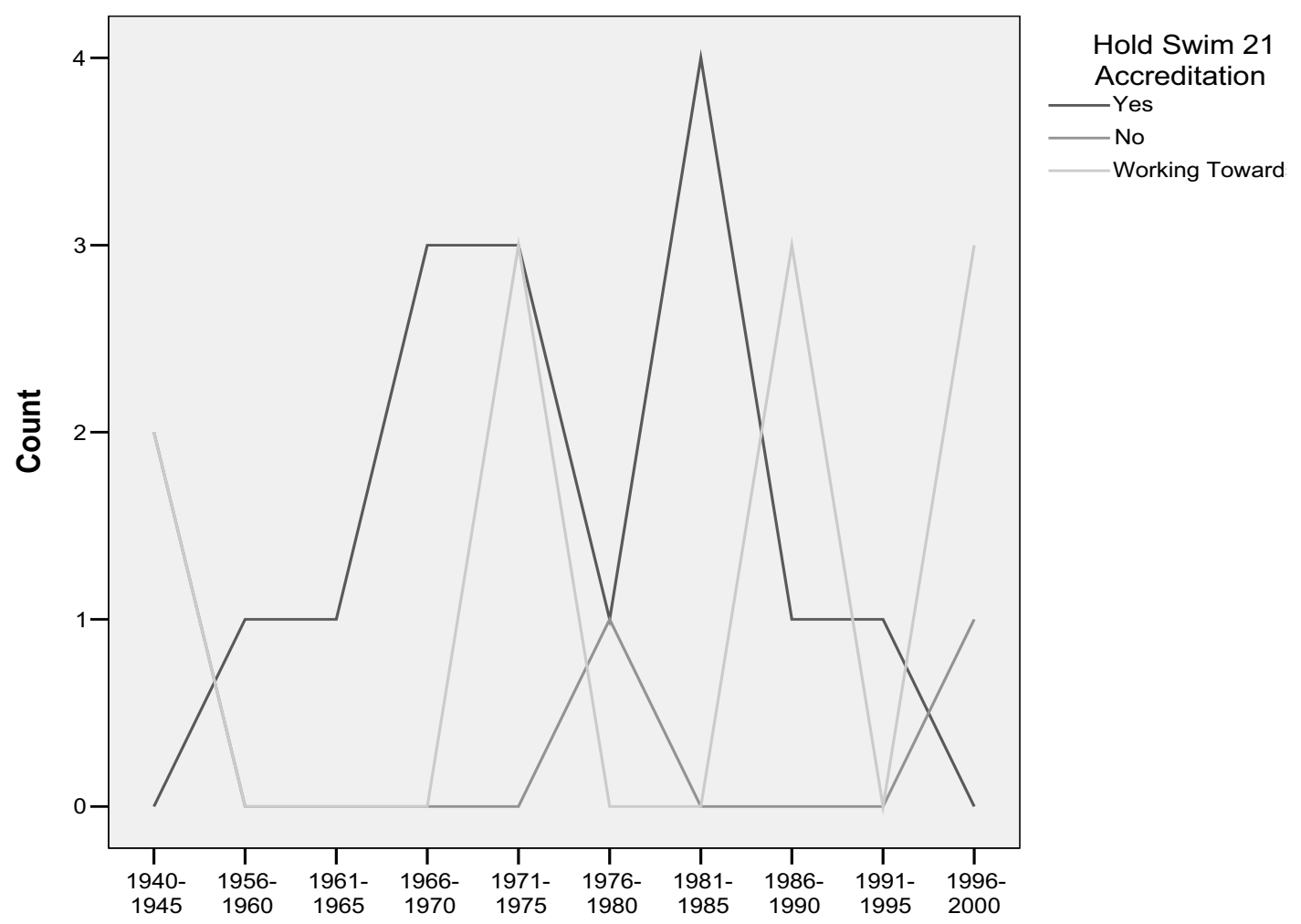

Figure 7. Year in which the club was formed impacting decisions to undertake change through gaining Swim 21 accreditation 